\title{
Early Detection of Leifsonia xyli subsp. xyli in Sugarcane Leaves by Real-Time Polymerase Chain Reaction
}

\author{
M. P. Grisham, Y.-B. Pan, and E. P. Richard, Jr., United States Department of Agriculture-Agricultural Research \\ Service, SRRC, Sugarcane Research Unit, Houma, LA
}

\begin{abstract}
Grisham, M. P., Pan, Y.-B., and Richard, E. P., Jr. 2007. Early detection of Leifsonia xyli subsp. $x y l i$ in sugarcane leaves by real-time polymerase chain reaction. Plant Dis. 91:430-434.

A real-time, polymerase chain reaction (PCR) assay was developed for detecting Leifsonia xyli subsp. xyli in sugarcane leaf tissue. Real-time PCR assays were conducted on the youngest, fully expanded leaf of three cultivars collected bi-weekly from field nurseries between 11 April and 19 July 2005. L. xyli subsp. xyli infection was detected in leaves collected at all sampling dates, including those from 1-month-old plants on 11 April. Assays conducted on older, more rapidly growing plants (28 July and 21 October 2005) indicated that leaf position affects assay efficiency. Conventional PCR was less efficient than real-time PCR for detecting $L$. xyli subsp. xyli in leaf tissue. Real-time PCR was used to rank cultivars for susceptibility to L. xyli subsp. xyli infection based on the relative titer of $L$. xyli subsp. xyli in leaves of inoculated, 3- and 4-monthold greenhouse-grown plants. The ranking of cultivars by real-time PCR was in close agreement with the ranking determined by tissue-blot enzyme immunoassay performed on tissue from 7- to 9-month-old stalks.
\end{abstract}

Sugarcane plants infected with Leifsonia xyli subsp. xyli (formerly Clavibacter xyli subsp. xyli) $(9,11)$, the cause of ratoon stunting disease (RSD), produce no characteristic external sign or symptom of the disease. Commonly used immunoassays lack the sensitivity to detect low titer of $L$. $x y l i$ subsp. xyli in leaf tissue, but are effective for detecting L. xyli subsp. xyli in stalk tissue of plants more than 5 months old where the bacterial titer is higher. The inability to assay plants prior to stalk formation prevents timely field diagnosis.

L. xyli subsp. xyli is transmitted from field to field in systemically infected stalks or cuttings (seed cane) used to establish new fields (17). Within-field spread occurs mechanically, primarily during harvesting operations $(21,22)$. Therefore, the primary strategy for controlling RSD is to establish a new crop with pathogen-free seed cane and to practice effective sanitation procedures to prevent plant-to-plant spread dur-

Corresponding author: M. P. Grisham E-mail: mgrisham@srrc.ars.usda.gov

Mention of a trademark, proprietary product, or vendor does not constitute a guarantee or warranty of the product by the United States Department of Agriculture and does not imply its approval to the exclusion of other products or vendors that may also be suitable.

Accepted for publication 23 October 2006.

doi:10.1094/PDIS-91-4-0430

This article is in the public domain and not copyrightable. It may be freely reprinted with customary crediting of the source. The American Phytopathological Society, 2007. ing the crop cycle. A crop cycle consists of an annual harvest that begins with a plantcane crop (first-year crop) followed by multiple ratoon crops.

Options for creating pathogen-free seed cane include heat treatment to eliminate the bacterium $(2,15)$ and the micropropagation of seed cane from foundation plants that test negative for $L$. xyli subsp. xyli (20). To minimize the opportunity for $L$. xyli subsp. xyli to reinfect healthy cane during planting and harvest, all cutting implements should be disinfested, especially the cutting surfaces of mechanical harvesters (17).

Techniques to diagnose infected plants in seed cane nurseries and production fields are needed to ensure that seed cane has minimal incidence of RSD and that sanitation practices are effective in preventing infection of production fields. Laboratory-based techniques are required for effective diagnosis because $L$. xyli subsp. xyli infection does not cause any characteristic external sign or symptom in sugarcane (15). The primary diagnostic techniques used include microscopy, serological tests, host-induced response, and DNA-based methods (17). The appropriate application of the different techniques depends on several factors, including the distribution and titer of the bacterium in the host plant, the use and urgency of the results, quantity of samples for processing, and availability of equipment and skilled labor (17).

L. xyli subsp. xyli is a xylem-inhabiting bacterium and, although infection is systemic in the sugarcane plant, the titer of the bacterium varies among the tissues.
Diagnosis typically has focused on the stalk because bacterial titer is highest there. In the stalk, maximum titer is reached first in the basal internode and then in internodes progressively toward the apex of the stalk (18). Reliable and accurate diagnosis is dependent on the sensitivity of the diagnostic protocol, tissue selection, and timing of sample collection $(17,22)$.

The most commonly used technique for monitoring RSD in Louisiana is the tissueblot enzyme immunoassay (TB-EIA) $(8,22)$. In a comparison of five diagnostic protocols-TB-EIA; evaporative-binding (EB)-EIA (5); dot-blot (DB)-EIA (19); dark-field microscopy (1); and alkalineinduced red autofluorescence (AIMA), a host-induced response (6) - TB-EIA was the most accurate (22).

Several DNA-based diagnostic methods are highly specific and more sensitive than other methods $(10,12,26,27,31)$. However, polymerase chain reaction (PCR) assays and other DNA-based methods applied directly from sap or other plant tissues were much less sensitive than detection in axenic cultures of the bacterium $(10,26)$. Some improvement in efficiency was made by adding specific reagents such as polyvinylpyrrolidone and Ficoll to reduce the effect of PCR inhibitors $(12,26)$, submitting the sap to a freeze-thaw cycle (27), or the separation of bacterial cells from the sap by differential centrifugation (10).

Real-time PCR increasingly is applied to the diagnosis and quantification of plant pathogens $(13,23,29,30)$. Real-time PCR offers increased sensitivity $(3,23,24)$, is sequence specific $(27,32)$, and is less labor intensive than conventional PCR because post-amplification processing is not required $(28,32)$. With real-time PCR, the amplified product is monitored progressively through the incorporation of fluorescent molecules in the reaction. Fluorescence intensity is correlated to PCR product production (32).

In the temperate climate of Louisiana, sugarcane planting occurs when the seed cane is 4 to 6 months old (mid-July to midSeptember). To provide growers with RSD diagnosis of potential seed cane, testing for L. xyli subsp. xyli infection needs to be completed before the start of planting. At this and earlier stages of growth, TB-EIA for RSD diagnosis is inconsistent and inaccurate (M. P. Grisham, unpublished). Consequently, a more sensitive diagnostic 
technique is needed for consistent and accurate early-season detection of $L$. xyli subsp. xyli-infected plants. The objectives of this study were to develop a real-time PCR protocol for the in vivo detection of L. xyli subsp. xyli, to test the efficiency of the real-time PCR protocol at different stages of plant growth, and to determine the effectiveness of ranking sugarcane cultivars for susceptibility to L. xyli subsp. $\mathrm{x} y l i$ infection at an early stage of plant growth with real-time PCR.

\section{MATERIALS AND METHODS}

Sample collection. Sugarcane plants for testing were identified in an RSD nursery at the United States Department of Agriculture, Agricultural Research Service, Sugarcane Research Laboratory research farm in Shriever, LA. In 2002, to establish plots with RSD-affected plants, single-bud cuttings were dip inoculated in juice extracted from $L$. xyli subsp. xyli-infected stalks, germinated in the greenhouse, and transplanted to the field after approximately 4 months of growth. Control plots were established from single-bud cuttings taken from stalks that had been immersed in a $50^{\circ} \mathrm{C}$, circulating hot-water bath for 2 $\mathrm{h}(2)$.

The youngest fully expanded leaf with a visible dewlap (the collar between the leaf blade and sheath) was collected from eight plants of three cultivars on each sampling date, four from L. xyli subsp. xyliinoculated plants and four from the control plots. Cultivars included L 62-96, a highly susceptible cultivar; CP 70-321, an intermediately susceptible cultivar; and CP 5268, a resistant cultivar (16; M. P. Grisham, unpublished data). The plants were from the second-ratoon crop of the nursery. Samples were collected on 11 and 26 April, 10 and 24 May, 14 and 28 June, and 19 July 2005. On the 19 July sampling date, there was sufficient stalk development to also collect a sample of the most basal, aboveground internode, including the adjacent nodal tissue.

Leaf samples were stored at $-20^{\circ} \mathrm{C}$ until analyzed by conventional and real-time PCR. The stalk samples were processed the same day for TB-EIA analysis following the protocol developed by Harrison and Davis (18).

To determine the effect of collecting samples from leaves at different positions on the stalk, two sets of samples were collected for real-time PCR analysis. On 28 July, leaves were collected from $L$. xyli subsp. xyli-inoculated plots of CP 70-321 and L 62-96. In addition to the youngest fully expanded leaf, the next five leaves below it also were collected. The leaves were designated as leaf 1 (the youngest leaf), then leaves $2,3,4,5$, and 6 , with leaf 6 being the most basal and the oldest. As on 28 July, samples collected on 21 October consisted of six leaves per stalk; however, sample collection was expanded to include leaves from L. xyli subsp. xyliinoculated and hot-water-treated plots of the three test cultivars.

On 9 September, leaf 5 was collected from eight plants of each of the three cultivars (four from $L$. xyli subsp. xyliinoculated and four from control plots) for real-time and conventional PCR assay. Basal internode samples also were collected on 9 September from all treatments for TB-EIA analysis.

Primer design and real-time PCR conditions. Primers were designed using Beacon Designer 2 software (Palo Alto, CA) specifically for real-time PCR and selected to amplify relatively short fragments. Initially, primers were designed within the 438-bp product amplified with the primer set developed by Pan et al. (26) for PCR detection of $L$. xyli subsp. xyli. Among the potential primer pairs identified, primers Lxx82F (TTCAACGCA GAAATTGTCCAGG) and Lxx22R (CAA GCAGGCGTACTAAGTTCGA) were selected. They amplified a 139-bp fragment. The optimal annealing temperature was $64^{\circ} \mathrm{C}$. For the last two sample collections (9 September and 21 October), another set of primers was designed from the intergenic transcribed spacer (ITS) region of $16 \mathrm{~S}-23 \mathrm{~S}$ ribosomal DNA of $L$. xyli subsp. xyli (GenBank accession number AF056003). The specificity of both primer sets was checked by alignments with GenBank sequences using the standard nucleotide-nucleotide BLAST (blastn; provided online by the National Center for Biotechnology Information). Among the potential primer pairs identified, primers Lxx202F (CGAACTTAGTACGCCTCGTTG) and Lxx331R (GGATTCGGTTCTCATCTC AGC) were selected. They amplified a 130-bp fragment. The optimal annealing temperature was $60^{\circ} \mathrm{C}$. All primers were commercially synthesized by Integrated DNA Technologies (Coralville, IA).

Leaf DNA extraction and real-time PCR amplification. Total DNA was extracted from approximately $200 \mathrm{mg}$ of leaf tissue as described by Pan et al. (25). The real-time PCR reactions were performed in the iCycler iQ Real-Time PCR Detection System (Bio-Rad Laboratories, Inc., Hercules, CA) and were carried out in 96-well reaction plates. Each reaction mixture contained $1 \mu \mathrm{l}$ of sample, $7 \mu \mathrm{l}$ of SYBR green master mix, $0.1 \mu \mathrm{l}$ of forward primer, $0.1 \mu \mathrm{l}$ of reverse primer, and $5.8 \mu \mathrm{l}$ of distilled water. Two sources of SYBR green master mix (iQ SYBR Green Supermix; Bio-Rad Laboratories, Inc., and SYBR Green PCR Master Mix; Applied Biosystems, Foster City, CA) were used with comparable results (data not shown). Negative control reactions contained the same mixtures with $0.1 \mu \mathrm{l}$ of sterile water replacing the sample. Thermal cycling conditions consisted of $5 \mathrm{~min}$ at $95^{\circ} \mathrm{C}$ followed by 40 cycles each consisting of denaturation for $10 \mathrm{~s}$ at $95^{\circ} \mathrm{C}$, annealing for
$30 \mathrm{~s}$ at $64^{\circ} \mathrm{C}$ (primer set $\mathrm{Lxx} 82 \mathrm{~F} / \mathrm{Lxx} 22 \mathrm{R}$ ) or $60^{\circ} \mathrm{C}(\mathrm{Lxx} 202 \mathrm{~F} / \mathrm{Lxx} 331 \mathrm{R})$, and extension for $10 \mathrm{~s}$ at $72^{\circ} \mathrm{C}$. After the final amplification cycle, a melting-curve analysis was performed to confirm specific amplification $(24,27)$. The expected product of 139-bp from the first set of primers had a melting temperature $\left(\mathrm{T}_{\mathrm{m}}\right)$ of $87^{\circ} \mathrm{C}$; the second primer pair was expected to produce a 130-bp fragment with a $\mathrm{T}_{\mathrm{m}}$ of $86^{\circ} \mathrm{C}$. Data analysis was carried out with the manufacturer's software (Optical System Software, v. 3.0; BioRad Laboratories, Inc.). The nucleotide sequences of the PCR products were determined on CEQ 8000 Genetic Analysis System (Beckman Coulter, Inc., Fullerton, CA) following the manufacturer's protocol. Conventional PCR was conducted using primers and thermocycle program as described by Pan et al. (26).

Assessing cultivar resistance. Stalks of nine sugarcane cultivars were hot-water treated (2) as described above to eliminate L. xyli subsp. xyli infection, and then cut into single-bud sets. One group of singlebud cuttings of each cultivar was dip inoculated with juice extracted from $L$. xyli subsp. xyli-infected stalks, planted in 15$\mathrm{cm}$-diameter pots filled with potting soil, and placed in the greenhouse, and another group of cuttings was planted without inoculation. Three months after inoculation, three plants from inoculated buds and three from noninoculated buds were selected for the study within each cultivar. Selected plants were similar in size and development.

The youngest, fully expanded leaf was collected from each plant, total DNA was extracted, and real-time PCR amplification was performed as described above. Cultivars were ranked for susceptibility to $L$. $x y l i$ subsp. xyli infection based on their average threshold cycle $(\mathrm{Ct})$ values. The lower the $\mathrm{Ct}$ value for a cultivar, the higher the number of bacteria in the tissue sample (32). The real-time PCR analysis was repeated 1 month later (4 months after inoculation).

Ranking of cultivar susceptibility to $L$. xyli subsp. xyli infection based on realtime PCR analysis was compared with ranking based on percent vascular bundles colonized (CVB) determined with TB-EIA (18). The TB-EIA was performed on four 7- to 9-month-old stalks of each cultivar collected annually from the plant-cane, first-ratoon, and second-ratoon crops of the RSD nursery established in 2002. A longitudinal core from the lowest aboveground internode of each stalk was blotted on a nitrocellulose membrane, the membrane stained with a labeled antibody, and the percent CVB determined.

\section{RESULTS}

All leaf samples of the highly susceptible cv. L 62-96 collected between 11 April and 19 July from L. xyli subsp. xyli- 
inoculated plots were diagnosed as positive for $L$. xyli subsp. xyli infection using realtime PCR (Table 1). Six leaf samples from the hot-water-treated plots of L 62-96 also tested positive (Table 1). For the intermediately susceptible cultivar CP 70-321, all leaves from the $L$. xyli subsp. xyliinoculated plots tested positive for $L$. xyli subsp. xyli infection with real-time PCR, except for the first two sampling dates and the 19 July date, whereas only one sample from the hot-water-treated plot tested positive (Table 1).

For the first four sampling dates, diagnosis with conventional PCR indicated that all samples of L 62-96 were positive for $L$. xyli subsp. xyli infection, in agreement with the real-time PCR results (Table 1). The proportion of samples testing positive, however, declined to 75,50 , and $0 \%$ with conventional PCR on the last three sampling dates, respectively. Only about $23 \%$ of the samples testing positive among the leaves collected from the $L$. xyli subsp. xyli-inoculated plots of CP 70321 by real-time PCR tested positive by conventional PCR (Table 1). No sample from a hot-water-treated plot of L 62-96 or CP 70-321 tested positive with conventional PCR. No sample collected from $L$. xyli subsp. xyli-inoculated or hot-watertreated plots of CP 52-68 (L. xyli subsp. $\mathrm{x} y l i$ resistant) tested positive with realtime or conventional PCR for the April 11 to July 19 sampling dates (data not shown).

Sufficient stalk tissue to employ TB-EIA for $L$. xyli subsp. xyli infection testing did not develop until 19 July. All four samples of L 62-96, three of four samples of CP 70321, and none of CP 52-68 from L. xyli subsp. xyli-infected plots tested positive for L. xyli subsp. xyli infection. The L 62-96 samples from the L. xyli subsp. xyli-infected plots were also positive with the real-time PCR; however, only one CP 70-321 sample was positive for $L$. xyli subsp. xyli infection with real-time PCR (Table 1).
Plants infected with L. xyli subsp. xyli were detected by real-time PCR on each sampling date; however, a decline in the proportion of positive assays occurred across all samples, from an average of $42 \%$ of the samples positive over the first five sampling dates to 31 and $19 \%$ on the sixth (28 June) and seventh (19 July) sampling dates, respectively (Table 1). The youngest leaf with a visible dewlap was chosen for analysis because it is an easily identifiable tissue source and, as such, provides a degree of consistency among samples collected from different cultivars, at different growth stages, and by different collectors. Real-time PCR assay of the youngest, fully expanded leaf and the five leaves basal to it collected on 28 July from L. xyli subsp. xyli-infected plots of L 62-96 and CP 70-321 showed that the largest number of positive samples was those from leaf number 5 (Table 2).

When the first set of primers (Lxx82F/Lxx22R) was developed, they appeared to meet the guidelines provided by the manufacture of the iCycler iQ RealTime PCR Detection System (Bio-Rad
Laboratories, Inc.), including absence of nonspecific products such as primerdimers. Testing of the primer design was conducted using samples containing high numbers of target DNA (high numbers of L. xyli subsp. xyli bacteria); however, under conditions of low titer of the target DNA, melt curve analysis indicated the coamplification of a nonspecific product $\left(\mathrm{T}_{\mathrm{m}}\right.$ of $\left.78^{\circ} \mathrm{C}\right)$ with the specific product $\left(\mathrm{T}_{\mathrm{m}}\right.$ of $87^{\circ} \mathrm{C}$ ). Gel analysis confirmed that the larger real-time PCR product was $139 \mathrm{bp}$, corresponding to the expected size of the specific product.

As recommended when nonspecific products are produced, a new primer set was designed for detecting $L$. xyli subsp. $\mathrm{xyli}$ (Lxx202F/Lxx331R) that produced a single melting peak, a single band of expected size on the electrophoresis gel, and the expected nucleotide sequence (24). This primer set was used for the samples analyzed on 9 September and 21 October (Tables 2 and 3). A number of samples collected between 11 April and 19 July were reanalyzed using the redesigned primers. Earlier diagnosis was confirmed

Table 2. Effect of leaf position as source of tissue for diagnosis of Leifsonia xyli subsp. xyli infection in a sugarcane plant as determined by real-time polymerase chain reaction

\begin{tabular}{llllllll}
\hline & & \multicolumn{7}{c}{ Leaf position $^{\mathbf{a}}$} \\
\cline { 4 - 8 } Collection date, cultivar & Source $^{\mathbf{b}}$ & $\mathbf{1}$ & $\mathbf{2}$ & $\mathbf{3}$ & $\mathbf{4}$ & $\mathbf{5}$ & $\mathbf{6}$ \\
\hline 28 July & & & & & & & \\
L 62-96 & RSD & 3 & 4 & 4 & 4 & 4 & 4 \\
CP 70-321 & RSD & 1 & 1 & 1 & 1 & 4 & 3 \\
21 October & & & & & & & \\
L 62-96 & RSD & 4 & 4 & 4 & 4 & 4 & 4 \\
CP 70-321 & HWT & 1 & 2 & 2 & 3 & 2 & 2 \\
CP 52-68 & RSD & 0 & 2 & 2 & 1 & 3 & 2 \\
& HWT & 0 & 0 & 0 & 0 & 0 & 0 \\
\hline
\end{tabular}

${ }^{\text {a }}$ Position $1=$ the youngest, fully expanded leaf with a visible dewlap; $2=$ leaf immediately basal to leaf $1 ; 3=$ leaf immediately basal to leaf 2; and so on. Data indicate number of plants positive for $L$. xyli subsp. xyli infection out of four plants assayed.

${ }^{\mathrm{b}}$ Nursery source. RSD = samples collected from L. xyli subsp. xyli-inoculated nursery plot, and HWT = samples collected from hot-water-treated nursery plot.

Table 1. Comparison of diagnostic techniques for detecting Leifsonia xyli subsp. xyli infection of sugarcane ${ }^{a}$

\begin{tabular}{|c|c|c|c|c|c|c|c|c|c|}
\hline \multirow[b]{3}{*}{ Date } & \multicolumn{4}{|c|}{ LCP 62-96 (susceptible) } & \multicolumn{4}{|c|}{ CP 70-321 (intermediately susceptible) } & \multirow[b]{3}{*}{ Positive $(\%)^{b}$} \\
\hline & \multicolumn{2}{|c|}{ Real-time PCR } & \multicolumn{2}{|c|}{ Conventional PCR } & \multicolumn{2}{|c|}{ Real-time PCR } & \multicolumn{2}{|c|}{ Conventional PCR } & \\
\hline & RSD & HWT & RSD & HWT & RSD & HWT & RSD & HWT & \\
\hline \multicolumn{10}{|l|}{ April } \\
\hline 11 & $4^{c}$ & 0 & 4 & 0 & 2 & 1 & 0 & 0 & 34 \\
\hline 26 & 4 & 2 & 4 & 0 & 3 & 0 & 1 & 0 & 44 \\
\hline \multicolumn{10}{|l|}{ May } \\
\hline 10 & 4 & 1 & 4 & 0 & 4 & 0 & 2 & 0 & 47 \\
\hline 24 & 4 & 0 & 4 & 0 & 4 & 0 & 1 & 0 & 41 \\
\hline \multicolumn{10}{|l|}{ June } \\
\hline 14 & 4 & 2 & 3 & 0 & 4 & 0 & 1 & 0 & 44 \\
\hline 28 & 4 & 0 & 2 & 0 & 4 & 0 & 0 & 0 & 31 \\
\hline \multicolumn{10}{|l|}{ July } \\
\hline 19 & 4 & 1 & 0 & 0 & 1 & 0 & 0 & 0 & 19 \\
\hline
\end{tabular}

a Analysis performed on total DNA extracted from tissues of the youngest, fully expanded leaf with a visible dewlap using cetyltrimethylammonium bromide extraction buffer procedure. $\mathrm{PCR}=$ polymerase chain reaction, RSD = samples collected from $L$. xyli subsp. xyli-inoculated nursery plot, and HWT $=$ samples collected from hot-water-treated nursery plot.

${ }^{\mathrm{b}}$ Positive for L. xyli subsp. xyli.

${ }^{\mathrm{c}}$ Each value is the number of samples testing positive for $L . x y l i$ subsp. xyli infection out of four samples tested. 
without the production of nonspecific products (data not shown).

Among the four leaf samples of each cultivar collected on 9 September, four samples of L 62-96, three of CP 70-321, and two of CP 52-68 from L. xyli subsp. xyli-inoculated plots tested positive for $L$. xyli subsp. xyli infection when analyzed with real-time PCR utilizing the redesigned primer set (Table 3). One L 62-96 and one CP 70-321 sample from the hotwater-treated plots tested positive for $L$. xyli subsp. xyli infection. No sample tested positive when analyzed with conventional PCR. TB-EIA analysis also indicated that the L 62-96 sample from the hot-watertreated plot was positive; however, the $\mathrm{CP}$ 70-321 sample from the hot-water-treated plot and the two CP 52-68 samples from the $L$. xyli subsp. xyli-inoculated plots tested negative with the TB-EIA assay (Table 3). All samples of L 62-96 and CP 70-321 from the L. xyli subsp. xyliinoculated plots tested positive with TBEIA.

The ranking of the nine cultivars for susceptibility to L. xyli subsp. xyli infection using real-time PCR was similar for the two sampling dates (Table 4), and the ranking by real-time PCR also was in close agreement with the ranking determined by TB-EIA.

\section{DISCUSSION}

Real-time PCR was effective in detecting L. xyli subsp. xyli infections at all stages of plant growth, including early in the season, when leaves were the only aboveground tissues available for sampling and assaying. The ability to collect diagnostic samples earlier in the season before the plant lodges improves sampling coverage because of better access to fields. Coverage of fields also can be improved by pooling leaf samples for real-time PCR diagnosis. If a pooled sample tests positive, the diagnostician has the option to separate the samples and run them individually.

Growth of test plants was initiated approximately 4 weeks prior to the first sampling date; however, the growth rate was slow because of cool weather and soil temperatures. The lower detection level observed in cv. CP 70-321 for the earliest sampling dates (Table 1) suggests that detectable titer levels in leaves of intermediately susceptible cultivars may not be found until more active growth is sustained.

TB-EIA is limited to sampling after the formation of stalk tissue. For most cultivars grown in Louisiana, stalks with one or more fully expanded internodes do not occur until late June or early July. In this study, stalk tissue was not available to perform TB-EIA until the 19 July sampling date. Also, in collecting stalk tissue for TB-EIA or other techniques that require a high titer of bacteria found in the vascular sap of the mature internodes, the stalk must be cut. The loss of a few stalks in a seed cane or production field is not critical; however, destructive sampling can be a problem in some situations. For example, a nondestructive sampling would be useful for the RSD diagnosis of critical foundation plants used in micropropagation operations or when indexing plant material in quarantine programs.

Gillaspie (14) developed a nondestructive method of RSD diagnosis. Basal parts of the oldest leaves were centrifuged at low speed and the centrifugal fluid then was examined by phase-contrast microscopy for the presence of $L$. xyli subsp. xyli bacterial cells. He reported detection of $L$. xyli subsp. xyli in some samples collected as early as 30 April. The limitation of this method is the effort required to set up the centrifugation and the labor and skill needed for the microscopic examination of the sample. The study did establish that $L$. xyli subsp. xyli bacterial cells could be recovered from leaves of young plants.

The samples that tested positive for $L$. xyli subsp. xyli infection by conventional PCR also tested positive by real-time PCR (Table 1); however, real-time PCR was more effective in identifying $L$. xyli subsp. $x y l i$-infected plants in the intermediately susceptible cv. CP 70-321 and in the resistant cv. CP 52-68 and among samples from later sampling dates and from hot-watertreated plots. Pan et al. (26) improved the sensitivity of the conventional PCR protocol when analyzing juice from stalks with the addition of polyvinylpyrrolidone and Ficoll to reduce the effects of PCR inhibitors. These were not included in the protocol used in this study because, in preliminary studies that included only early growth stage-infected leaves of the highly susceptible cv. LCP 62-96, their use did not appear necessary. In future comparisons of real-time PCR and conventional PCR, these materials should be added to the conventional PCR reaction buffer. Even with increased sensitivity of conventional PCR, an advantage of real-time PCR is that no post-reaction analysis of the PCR products on gel electrophoresis is required, resulting in reduced experimental time and increased throughput.

The youngest, fully expanded leaf appeared to be a good source of tissue for diagnosis in plants prior to the development of stalks; however, after stalk devel-

Table 3. Comparison of diagnostic techniques for detecting Leifsonia xyli subsp. xyli infection in leaf 5 of approximately 7 -month-old sugarcane stalks (9 September 2005) ${ }^{\mathrm{a}}$

\begin{tabular}{lccc}
\hline Cultivar, source $^{\mathbf{b}}$ & Real-time PCR & Conventional PCR & TB-EIA \\
\hline L 62-96 & 4 & 0 & 4 \\
RSD & 1 & 0 & 1 \\
HWT & 3 & 0 & 4 \\
CP 70-321 & 1 & 0 & 0 \\
RSD & & & \\
HWT & 2 & 0 & 0 \\
CP 52-68 & 0 & 0 & 0 \\
RSD & & & \\
HWT & & 0 & \\
\hline
\end{tabular}

${ }^{a}$ Leaf 5 is the fourth leaf basal to leaf 1 (the youngest, fully expanded leaf with a visible dewlap). PCR $=$ polymerase chain reaction and TB-EIA = tissue-blot enzyme immunoassay. Data indicate number of plants positive for $L$. xyli subsp. xyli infection out of four plants assayed.

${ }^{\mathrm{b}}$ Nursery source. RSD = samples collected from $L$. xyli subsp. xyli-inoculated nursery plot, and HWT $=$ samples collected from hot-water-treated nursery plot.

Table 4. Comparison of real-time polymerase chain reaction (PCR) and tissue-blot enzyme immunoassay (TB-EIA) for ranking nine sugarcane cultivars for susceptibility to Leifsonia xyli subsp. xyli infection

\begin{tabular}{|c|c|c|c|c|c|}
\hline \multicolumn{4}{|c|}{ Real-time PCR } & \multirow{2}{*}{\multicolumn{2}{|c|}{ TB-EIA }} \\
\hline \multicolumn{2}{|c|}{ 3-month-old plant } & \multicolumn{2}{|c|}{ 4-month-old plant } & & \\
\hline Cultivar & Mean $\mathbf{C t}^{\mathbf{a}}$ & Cultivar & Mean $\mathbf{C t}^{\mathrm{a}}$ & Cultivar & Mean CVB $(\%)^{b}$ \\
\hline Но 95-988 & - & Но 95-988 & - & Но 95-988 & 2 \\
\hline CP 52-68 & 37.4 & LCP 85-384 & 38.3 & CP 52-68 & 5 \\
\hline НоСР 96-540 & 35.5 & CP 52-68 & 37.4 & НоСР 96-540 & 9 \\
\hline LCP 85-384 & 35.0 & НоСР 96-540 & 30.8 & LCP 85-384 & 23 \\
\hline L 99-226 & 27.7 & L 99-226 & 28.6 & CP 70-321 & 41 \\
\hline СР 70-321 & 26.0 & СР 70-321 & 27.4 & L 99-226 & 69 \\
\hline НоСР 00-950 & 25.8 & НоСР 00-950 & 27.7 & НоСР 00-950 & 77 \\
\hline L 99-233 & 24.8 & L 99-233 & 26.0 & L 99-233 & 86 \\
\hline L 62-96 & 23.5 & L 62-96 & 25.9 & L 62-96 & 94 \\
\hline
\end{tabular}

a Threshold cycle $(\mathrm{Ct})$ number when fluorescence of sample exceeded background fluorescence. Lower $\mathrm{Ct}$ number indicates fewer PCR cycles necessary for detection because of the presence of a greater number of $L$. xyli subsp. xyli bacteria in sample. The greater the $\mathrm{Ct}$ number, the more resistant the cultivar; $\mathrm{n}=3 ;-=$ fluorescence of sample did not exceed background.

${ }^{\mathrm{b}} \mathrm{CVB}=$ colonized vascular bundles; $n=12$. 
opment was initiated, the choice of older, more mature leaves may improve efficiency of the RSD diagnosis. The reduced efficiency of detecting L. xyli subsp. xyli by conventional PCR in L 62-96 also suggests that, at the older stages of plant growth, PCR inhibitors also build up in leaves (Table 3).

The detection of $L$. xyli subsp. xyli among samples collected from the hotwater-treated (control) plots created some initial concern. Factors that may explain $L$. xyli subsp. xyli infection among the control plants of L 62-96 include an incomplete eradication of $L$. xyli subsp. xyli during the hot-water treatment of the seed cane used to plant the control plots or the infection of the control plot during the two earlier harvests of the nursery. Although hot-water treatment of seed cane is highly effective at reducing infections of $L$. xyli subsp. xyli, complete elimination of the pathogen may not always occur $(2,7,15)$. The plants used in this study were from a second-ratoon nursery. As much care as possible was taken to prevent mechanical spread of $L$. $x y l i$ subsp. xyli to the control plots, including disinfecting the harvester cutting blades and harvesting the control plots first. With a highly susceptible cultivar such as L 62-96 that also supports a high titer of bacteria, potential for accidental spread of L. xyli subsp. xyli is higher than for other, less susceptible cultivars (22).

The ranking of cultivars for susceptibility to $L$. xyli subsp. xyli infection was in close agreement with the ranking determined by TB-EIA, a reliable and oftenused method to assess cultivar susceptibility to $\operatorname{RSD}(4,8,18,20,21)$. Currently in Louisiana, resistance to RSD is not a primary selection criterion for advancing candidate cultivars because an efficient method to evaluate clones at the early stages of the breeding program is not available and because the disease can be controlled with the use of pathogen-free seed cane and field sanitation. Real-time PCR offers the advantage that testing for resistance to RSD can be performed on plants prior to the development of mature stalks. Therefore, evaluations can be made in a timelier manner, and the number of cultivars that can be efficiently evaluated can be increased.

\section{ACKNOWLEDGMENTS}

This work was supported in part with grower and miller check-off funds administered by the American Sugar Cane League of the U.S.A., Inc., Thibodaux, LA. We thank S. Lingle for technical advice about real-time PCR, K. Warnke for conducting real-time PCR analysis, and M. Bonnette and J. Maggio for assistance collecting and processing samples.

\section{LITERATURE CITED}

1. Amiet, P. J. 1985. Field surveys for ratoon stunting disease using phase contrast microscopy. Proc. Aust. Soc. Sugar Cane
Technol. 7:109-111.

2. Benda, G. T. A., and Ricaud, C. 1978. The use of heat treatment for sugarcane disease control. Proc. Int. Soc. Sugar Cane Technol. 16:483496.

3. Balaji, B., Bucholtz, D. B., and Anderson, J. M. 2003. Barley yellow dwarf virus and Cereal yellow dwarf virus quantification by real-time polymerase chain reaction in resistant and susceptible plants. Phytopathology 93:1386-1392.

4. Comstock, J. C., Grisham, M. P., Irvine, J. E., and Miller, J. D. 1999. Ratoon stunting disease ratings for US mainland sugarcane cultivars. Sugar J. 58(2):28-29, 32-33.

5. Croft, B. J., Greet, A. D., Leaman, T. M., and Teakle, D. S. 1994. RSD diagnosis and varietal resistance screening in sugarcane using the EB-EIA technique. Aust. Soc. Sugar Cane Technol. 16:143-151.

6. Damann, K. E., Jr. 1988. Alkaline-induced metaxylem autofluorescence: a diagnostic symptom of ratoon stunting disease of sugarcane. Phytopathology 78:233-236.

7. Damann, K. E., Jr., and Benda, G. T. A. 1983. Evaluation of commercial heat-treatment methods for control of ratoon stunting disease of sugarcane. Plant Dis. 67:966-967.

8. Davis, M. J., Dean, J. L., Miller, J. D., and Shine, J. M., Jr. 1994. A method to screen for resistance to ratoon stunting disease of sugarcane. Sugar Cane 6:9-16.

9. Davis, M. J., Gillaspie, A. G., Jr., Vidaver, A. K., and Harris, R. W. 1984. Clavibacter: A new genus containing some phytopathogenic coryneform bacteria, including Clavibacter xyli subsp. xyli sp. nov., subsp. nov. and Clavibacter xyli subsp. cynodontis subsp. nov., pathogens that cause ratoon stunting disease of sugarcane and bermudagrass stunting disease. Int. J. Syst. Bacteriol. 34:107-117.

10. Davis, M. J., Rott, P., and Astua-Monge, G. 1998. Nested, multiplex PCR for detection of both Clavibacter xyli subsp. xyli and Xanthomonas albilineans in sugarcane. Abstract 3.3.4. in: Offered Papers Abstracts, Vol. 3, 7th Int. Congress Plant Pathol. Edinburgh, Scotland. International Society for Plant Pathology, Edinburgh.

11. Evtushenko, L. I., Dorofeeva, L. V., Subbotin, S. A., Cole, J. R., and Tiedje, J. M. 2000. Leifsonia poae gen. nov., sp. nov., isolated from nematode galls on Poa annua, and reclassification of 'Corynebacterium aquaticum' Leifson 1962 as Leifsonia aquatica (ex Leifson 1962) gen. nov., nom. rev., comb. nov. and Clavibacter xyli Davis et al. 1984 with two subspecies as Leifsonia xyli (Davis et al. 1984) gen. nov., comb. nov. Int. J. Syst. Evol. Microbiol. 50:371-380.

12. Fegan, M., Croft, B. J., Teakle, D. S., Hayward, A. C., and Smith, G. R. 1998. Sensitive and specific detection of Clavibacter xyli subsp. $x y l i$, causal agent of ratoon stunting disease, with a polymerase chain reaction-based assay. Plant Pathol. 47:495-504.

13. Gao, X., Jackson, T. A., Lambert, K. N., Li, S., Hartman, G. L., and Niblack, T. L. 2004. Detection and quantification of Fusarium solani f. sp. glycines in soybean roots with real-time quantitative polymerase chain reaction. Plant Dis. $88: 1372-1380$

14. Gillaspie, A. G. 1987. Method for detecting Clavibacter xyli subsp. xyli from sugarcane leaves. Plant Dis. 71:691-693.

15. Gillaspie, A. G., Jr., and Teakle, D. S. 1989. Ratoon stunting disease. Pages 59-80 in: Diseases of Sugarcane-Major Diseases. C. Ricaud, B. T. Egan, A. G. Gillaspie, Jr., and C.G. Hughes, eds. Elsevier, New York.

16. Grisham, M. P. 1991. Effect of ratoon stunting disease on yield of sugarcane grown in multi- ple three-year plantings. Phytopathology 81:337-340.

17. Grisham, M. P. 2004. Ratoon stunting disease. Pages 77-96 in: Sugarcane Pathology, Volume III: Bacterial and Nematode Diseases. G. P. Rao, A. S. Saumtally, and P. Rott, eds. Science Publishers, Inc., Enfield, NH.

18. Harrison, N. A., and Davis, M. J. 1988. Colonization of vascular tissues by Clavibacter xyli sub sp. $x y l i$ in stalks of sugarcane cultivars differing in susceptibility to ratoon stunting disease. Phytopathology 78:722-727.

19. Harrison, N. A., and Davis, M. J. 1990. Comparison of serological techniques for diagnosis of ratoon stunting disease. Sugar Cane (Spring Suppl.):5-9.

20. Hoy, J. W., and Flynn, J. L. 2001. Control of ratoon stunting disease of sugarcane in Louisiana with seedcane produced through micropropagation and resistant cultivars. Proc. Int. Soc. Sugar Cane Technol. 24:417-421.

21. Hoy, J. W., and Grisham, M. P. 2006. Effects of harvester type, inoculum source, and cultivar on spread of ratoon stunting disease. Sugar Cane Int. 24(3):10-14.

22. Hoy, J. W., Grisham, M. P., and Damann, K. E., Jr. 1999. Spread and increase of ratoon stunting disease of sugarcane and comparison of disease detection methods. Plant Dis. 83:1170-1175.

23. Kokkinos, C. D., and Clark, C. A. 2006. Realtime PCR assays for detection and quantification of sweetpotato viruses. Plant Dis. 90:783788.

24. Lekanne-Deprez, R. H., Fijnvandraat, A. C., Ruijter, J. M., and Moorman, A. F. M. 2002 Sensitivity and accuracy of quantitative realtime polymerase chain reaction using SYBR green depends on cDNA conditions. Anal. Biochem. 307:63-69.

25. Pan, Y.-B., Burner, D. M., and Legendre, B. L. 2000. An assessment of the phylogenetic relationship among sugarcane and related taxa based on the nucleotide sequence of $5 \mathrm{~S}$ rRNA intergenic spacers. Genetica 108:285295.

26. Pan, Y.-B., Grisham, M. P., Burner, D. M., Damann, K. E., Jr., and Wei, Q. 1998. A polymerase chain reaction protocol for the detection of Clavibacter xyli subsp. xyli, the causal bacterium of sugarcane ratoon stunting disease. Plant Dis. 82:285-290.

27. Pan, Y.-B., Grisham, M. P., and Wei, Q. 2001 PCR diagnosis of sugarcane leaf scald and ratoon stunting disease. Proc. Int. Soc. Sugar Cane Technol. 24:607-608.

28. Ririe, K. M., Rasmussen, R. P., and Wittwer, C. T. 1997. Product differentiation by analysis of DNA melting curves during polymerase chain reaction. Anal. Biochem. 245:154-160.

29. Sayler, R. J., Cartwright, R. D., and Yang, Y. 2006. Genetic characterization and real-time PCR detection of Burkholderia glumae, a newly emerging bacterial pathogen of rice in the United States. Plant Dis. 90:603-610.

30. Schaad, N. W., Frederick, R. D., Shaw, J., Schneider, W. L., Hickson, R., Petrillo, M. D., and Luster, D.G. 2003. Advances in molecularbased diagnostics in meeting crop biosecurity and phytosanitary issues. Annu. Rev. Phytopathol. 41:305-324.

31. Taylor, P. W. J., Petrasovits, L. A., Van der Velde, R., Birch, R. G., Croft, B. J., Fegan, M., Smith, G. R., and Brumbley, S. M. 2003. Development of PCR-based markers for detection of Leifsonia xyli subsp. xyli in fibrovascular fluid of infected sugarcane plants. Australasian Plant Pathol. 32:367-375.

32. Wong, M. L., and Medrano, J. F. 2005. Realtime PCR for mRNA quantification. BioTechniques 39:75-85. 